DOI: 10.1002/adom.((please add manuscript number))

Article type: Communication

\title{
Polarized phosphorescence of isotropic and metal-based clustomesogens dispersed into chiral nematic liquid crystalline films
}

Simon M. Wood, Marianne Prévôt, Maria Amela-Cortes, Stéphane Cordier, Steve J. Elston, Yann Molard ${ }^{a}$ Stephen M. Morris ${ }^{b}$

Simon M. Wood, Prof. Steve J. Elston, Dr. Stephen M. Morris

Department of Engineering Science, University of Oxford, Parks Road, Oxford, OX1 3PJ, UK E-mail: a) yann.molard@univ-rennes1.fr; b) stephen.morris@eng.ox.ac.uk

Marianne Prévôt, Dr. Maria Amela-Cortes, Dr. Stephane Cordier, Dr. Yann Molard

UMR: "Institut des Sciences Chimiques de Rennes," UR1-CNRS 6226, Université de Rennes 1, Rennes, France

Keywords: ((chiral nematic liquid crystals; clustomesogens; phosphorescence))

Active optical devices that combine a light source, color generation and polarization control into a single element have been sought for many years ${ }^{[1]}$ with potential applications ranging from displays ${ }^{[2]}$ to quantum optics ${ }^{[3]}$ and optical information processing. ${ }^{[4]}$ As an example, a polarized light source would be of significant benefit to the liquid crystal (LC) display industry where polarized light is typically generated using a combination of an unpolarized white light source and linear absorptive polarizers, which results in losses and increases energy consumption. Quantum cryptography can use different polarization states of light to give different quantum representations of zero and one. ${ }^{[3]}$ Consequently, a means of generating polarized light that could be tuned to give different polarization states offer great advantages towards a number of photonic technologies.

Previous work has considered generating linearly polarized light using electroluminescent LC polymers that are aligned in one particular orientation ${ }^{[5]}$ and species dispersed into nematic LCs such as organic fluorescent dyes exploiting the dye-guest host effect ${ }^{[4,6]}$ and inorganic 
Submitted to

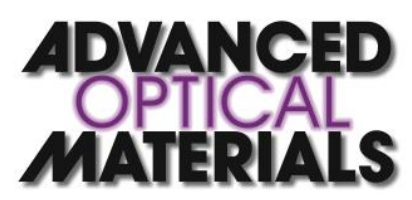

emitters like lanthanide-complexes. ${ }^{[7]}$ However, there are many applications for which circularly polarized (CP) light would be advantageous, including quantum cryptography ${ }^{[3]}$ and 3-dimensional autostereoscopic displays. ${ }^{[4]}$ Furthermore, the transmission-voltage curves for LC display devices have been found to be steeper when CP light is used instead of linearly polarized light. ${ }^{[8]}$

CP emission has been demonstrated using luminescent conjugated LC polymers ${ }^{[9,10]}$ and metallomesogens. ${ }^{[11,12]}$ Also, much work has focussed upon doping fluorophores into chiral LC phases - those that naturally self-organize into helicoidal structures with periodicities on the order of the wavelength of light. The most popular chiral LC phase used for this purpose is the chiral nematic phase. When doped with fluorescent compounds such that the reflection band (photonic band gap) overlaps the emission spectrum of the fluorophore, the emission is dominated by a specific CP determined by the rotation sense of the helix. These LC materials have the additional benefit that the molecular arrangement can be controlled externally using electric fields, allowing their polarization properties to be altered in-situ. A variety of fluorophores have been combined with such LCs, including organic materials like fluorescent dyes $^{[13]}$ and inorganic species such as lanthanides ${ }^{[12]}$ and quantum dots (QDs). ${ }^{[3,14-17]}$

However, these fluorophores have drawbacks - organic dyes are highly susceptible to photobleaching, ${ }^{[18]}$ curtailing their usefulness when illuminated continuously; inorganic compounds such as QDs, on the other hand, are typically restricted to very low concentrations by weight in the $\mathrm{LC}_{\text {host }}{ }^{[14]}$ or require complex preparation procedures ${ }^{[19]}$ and they typically exhibit low quantum efficiencies; alternative inorganic structures such as metallomesogens generally exhibit mesophase transition temperatures that are significantly greater than room temperature and poor thermal stabilities, making them less applicable to devices. ${ }^{[11]}$ 
In contrast, recently-developed transition metal clustomesogens composed of mesomorphic organic compounds and octahedral molybdenum clusters appear to circumvent some of these problems. ${ }^{[20]}$ They have been shown to be stable to continuous wave illumination, may be dispersed at high concentrations by weight into LC materials and are thermally stable to temperatures well above the LC clearing point. ${ }^{[20-30]}$ They exhibit high quantum yields $(0.59$ and 1 were reported in solution for $\left(n \mathrm{Bu}_{4} \mathrm{~N}\right)_{2} \mathrm{Mo}_{6} \mathrm{I}_{8}\left(\mathrm{OCOC}_{3} \mathrm{~F}_{7}\right)_{6}{ }^{[26]}$ and $\left(n \mathrm{Bu}_{4} \mathrm{~N}\right)_{2} \mathrm{Mo}_{6} \mathrm{I}_{8}\left(\mathrm{OCOCF}_{3}\right)_{6}$, respectively $\left.{ }^{[27]}\right)$ and strong photoluminescence $(\mathrm{PL})^{[21]}$ in nematic LC materials. ${ }^{[22,25]}$ However, their emission properties in chiral structures have never been explored. Here, we present a study on the strong influence of the chiral nematic LC photonic band-gap on the clustomesogen phosphoresence, resulting in strongly $\mathrm{CP}$ emission.

The two clustomesogens used here were $\operatorname{Trisel}_{2}\left[\mathrm{Mo}_{6} \mathrm{I}_{8}\left(\mathrm{OCOC}_{2} \mathrm{~F}_{5}\right)_{6}\right]$ and $\operatorname{Trisel}_{2}\left[\mathrm{Mo}_{6} \mathrm{I}_{8}\left(\mathrm{OCOC}_{3} \mathrm{~F}_{7}\right)_{6}\right]$ (Figure S1), both contain the $\left[\mathrm{Mo}_{6} \mathrm{I}_{8}\left(\mathrm{OCOC}_{n} \mathrm{~F}_{2 n+1}\right)\right]^{2-}(\mathrm{n}=2,3)$ anionic cluster unit - chosen for the excellent photo-physical properties reported for similar compounds. ${ }^{[26-27]}$ The two clustomesogens differ in the length of their fluorinated apical ligands but exhibit very similar properties such as the same quantum yield (0.7). ${ }^{[22]}$ The two materials were found to have indistinguishable emission and absorption windows. Our materials were prepared as reported by Amela-Cortes, et al. ${ }^{[28]}$ and described in the SI. Both compounds show nematic LC mesomorphic behavior from $20^{\circ} \mathrm{C}$ to around $64^{\circ} \mathrm{C}$.

Initially, we dispersed the clustomesogens into the well-known nematic LC mixture E7 (Merck KGaA), chosen for its well-characterized physical properties and because it exhibits a nematic phase at room temperature. Figure 1a shows optical polarizing microscopy images 


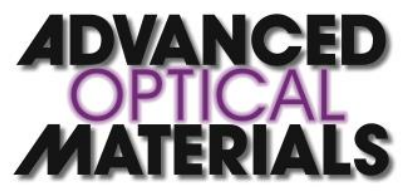

of both the bright and dark states of a $9 \mu$ m-thick planar aligned glass cell filled with a mixture of $20 \mathrm{wt} / \%$ clustomesogen in E7; the inset shows the visible PL from the mixture filled into a glass cell and illuminated with UV light. As shown in the figure, no aggregation of the CM is evident and the PL appears to be uniform across the sample.

The absorption spectrum for the mixture is shown in Figure $1 \mathrm{~b}$ (peak at $\lambda_{\mathrm{a}}=323 \mathrm{~nm}$ ) along with the deep-red PL (peak at $\lambda_{\mathrm{PL}}=657 \mathrm{~nm}$ ). These compounds exhibit a large Stoke's shift $(\Delta \lambda=334 \mathrm{~nm})$ as expected from materials based on Molybdenum clusters. The PL spectrum appears to show no linear-polarization dependence (Figure 1c) and the dichroic ratio is found to be $I_{\|} / I_{\perp} \sim 1$ (where $I_{\|}$and $I_{\perp}$ are the emission intensities parallel and perpendicular to the director, respectively) for all wavelengths. These results indicate that there is no discernible dye-guest host effect and, therefore, there is no difference in the emission into the two modes (i.e. between the mode parallel and the mode perpendicular to the nematic director).

To demonstrate the photo-stability of the clustomesogen-doped mixture under continuouswave illumination, the PL intensity was recorded over time and compared to that of an equivalent LC host mixture doped with $1.5 \mathrm{wt} \%$ of the laser dye DCM (4(Dicyanomethylene)-2-methyl-6-(4-dimethylaminostyryl-4H-pyran)). The results are shown in Figure 1d. It can be seen that the output for the dye mixture rapidly diminishes over time. Conversely, the output from the clustomesogen-doped nematic shows an increase in the PL initially with time before reaching a steady-state output without degradation of the emission intensity. Clearly, the output from the clustomesogen mixture is considerably more stable to the continuous illumination than the organic dye-doped mixture. The initial increase in the output of the clustomesogen has been noted before and may be attributed to a decrease of the 


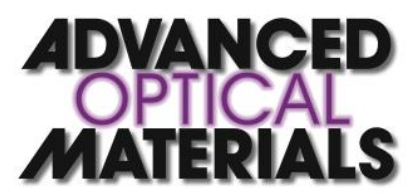

local molecular oxygen concentration around the emissive clusters during the first few minutes of irradiation in the LC host matrix. ${ }^{[28]}$

Subsequently, the clustomesogen was dispersed into a chiral nematic LC. The nematic LC ZLI-1840 (Merck KGaA) was used because it does not absorb UV wavelengths (unlike E7) where the clustomesogen absorbs. As ZLI-1840 is achiral, a chiral additive was used to form a chiral nematic phase (BDH1281, Merck KGaA); the concentration was chosen such that the centre of the band-gap coincided with the PL peak of the clustomesogen. Measurements of the clustomesogens in the nematic phase of ZLI-1840 revealed similar results to those presented for E7.

The transmission spectrum for both left- and right-handed CP white light is shown in Figure 2a, demonstrating that the band-gap only occurs for right-handed CP light (it has a righthanded helicoidal structure). There was good dispersal of the clustomesogen with no visible aggregation (Figure 2a, inset) in planar-aligned cells. Measurements of the PL emission for the two different CP modes are shown in Figure 2b. There is modification of the PL spectrum in the presence of the band-gap for RCP emission; the emission for the LCP mode resembles that of a nematic LC doped with the clustomesogens. As shown in Figure 2c, where the PL emission for right-handed CP light is overlaid with the transmission spectrum for white light, it is clear that the PL is suppressed within the band gap and enhanced at the band-edges due to the increase in the density of photon states (see SI Figure 2).

To quantify the degree of CP of the emitted light, we have used the dissymmetry factor, $g_{\mathrm{e}}$, which is a measure of the degree of CP light. ${ }^{[31]}$ It is defined as

$$
g_{e}=2 \frac{\left(I_{L}(\lambda)-I_{R}(\lambda)\right)}{\left(I_{L}(\lambda)+I_{R}(\lambda)\right)}
$$


Submitted to

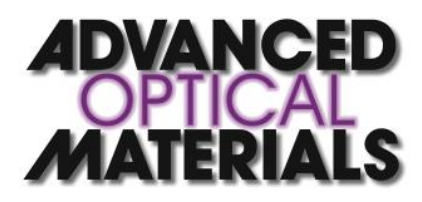

where $I_{\mathrm{L}}$ and $I_{\mathrm{R}}$ are the intensity of the left- and right-handed CP emission. $g_{\mathrm{e}}$ is wavelength dependent and varies from 0 (no $\mathrm{CP}$ ) to \pm 2 (complete left- or right-handed $\mathrm{CP}$ ). The dissymmetry factor for a well-annealed sample with a photonic band-gap centred at the peak of the PL is shown in Figure 2d. $g_{e}$ rises sharply to large positive values in the band gap where the emission consists of a large proportion of left CP light (i.e., $I_{\mathrm{L}} \gg I_{\mathrm{R}}$ ). Conversely, at the band-edges, the emission is mainly right-handed CP light - there is fluorescent enhancement of right-hand polarized light due to the large density of photon states. Outside of the bandgap, $g_{\mathrm{e}}$ oscillates between positive and negative values due to the variation in the density of photon states (c.f. Figure S2).

As Figure 1c shows that there is no dye-guest host effect between the nematic LC and the clustomesogen, $g_{\mathrm{e}}$ is entirely due to the photonic band structure that arises from the chiral LC structure and not from any preferential alignment of the clustomesogen in the LC. The maximum value of $g_{\mathrm{e}} \sim 1.6$ for the clustomesogen-chiral nematic mixture is comparable to literature values for other materials which vary from 0.3 for metallogen-based compounds ${ }^{[12]}$ to $\sim 1.8$ for fluorescent LC polymers. ${ }^{[10]}$ The value for $g_{\mathrm{e}}$ is found to vary slightly with cell thickness and is presented in the SI (Figure S3).

By applying an external electric-field to the LC device, the planar Grandjean alignment can be realigned to a nematic homeotropic alignment, in which the helicoidal structure is removed and there is no longer a photonic band gap for visible light. This is shown in Figure 3a where $g_{\mathrm{e}}$ is observed to diminish as the electric field increases and the helicoidal structure is

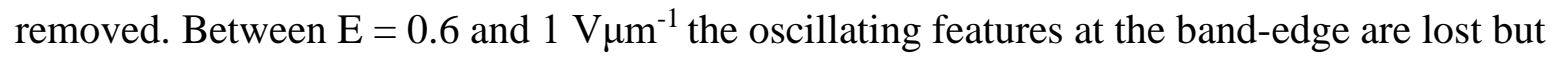
the band-gap is maintained and $g_{\mathrm{e}}$ remains positive across the wavelength region probed. At

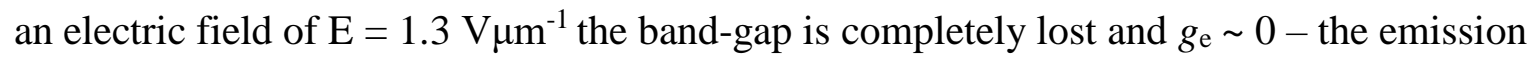
shows no circular polarisation. Figure $3 \mathrm{~b}$ shows the change in $g_{\mathrm{e}}$ at a fixed wavelength $(\lambda=$ 
Submitted to

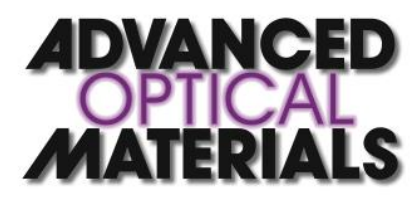

$670 \mathrm{~nm}$ ), demonstrating that it decreases as the electric field increases in a continuous manner corresponding to change from left CP light to unpolarised light.

To conclude, we have presented results on transition metal clustomesogen materials that can be combined with chiral nematic LCs to act as active and very stable circularly-polarized luminescent devices with polarization properties that may be manipulated in-situ by influencing the LC host, such as with electric-fields. This combination of materials offers potential for next generation light sources - including single photon sources and lowthreshold lasers.

\section{Experimental Section}

Chemicals: The nematic LCs used were E7 (Synthon) and ZLI-1840 (Merck). The high twisting power chiral dopant BDH1281 (Merck) was dispersed into the LCs to form a chiral nematic phase with a right-handed helical structure. The clustomesogens used were $\operatorname{Trisel}_{2}\left[\mathrm{Mo}_{6} \mathrm{I}_{8}\left(\mathrm{OCOC}_{2} \mathrm{~F}_{5}\right)_{6}\right]$ and $\operatorname{Trisel}_{2}\left[\mathrm{Mo}_{6} \mathrm{I}_{8}\left(\mathrm{OCOC}_{3} \mathrm{~F}_{7}\right)_{6}\right]$, synthesized by a metathesis reaction as described by Prévôt, et $\mathrm{al}^{[22]}$ and repeated in the SI.

\section{Sample preparation:}

Two LC/clustomesogen mixtures were used - one nematic mixture and one chiral nematic mixture with a band-gap centered at the phosphorescence maximum.

The nematic/clustomesogens mixture contained $20 \mathrm{wt} / \% \operatorname{Trisel}_{2}\left[\mathrm{Mo}_{6} \mathrm{I}_{8}\left(\mathrm{OCOC}_{3} \mathrm{~F}_{7}\right)_{6}\right]$ in E7 $\left(\mathrm{T}_{\text {iso }}=58.8^{\circ} \mathrm{C}\right)$. The chiral nematic LC contained $2.2 \mathrm{wt} / \%$ BDH1281 and $20 \mathrm{wt} / \%$ $\operatorname{Trisel}_{2}\left[\mathrm{Mo}_{6} \mathrm{I}_{8}\left(\mathrm{OCOC}_{2} \mathrm{~F}_{5}\right)_{6}\right]$ in ZLI-1840 (long band-edge $\sim 710 \mathrm{~nm}, \mathrm{~T}_{\mathrm{iso}}=95.6^{\circ} \mathrm{C}$ ). 
Submitted to

To create the chiral nematic LC, BDH1281 was added to the $\mathrm{LC}$, heated to $120^{\circ} \mathrm{C}$ for 2 hours and then left for $\sim 16$ hours above the isotropic temperature $\left(\sim 100^{\circ} \mathrm{C}\right.$ for ZLI-1840). To disperse the clustomesogen, this was added to the LC and heated to above the isotropic temperature $\left(70^{\circ} \mathrm{C}\right.$ for $\mathrm{E} 7$ and $100^{\circ} \mathrm{C}$ for ZLI-1840) for 24 hours. The fluorescent dye-doped mixture used in Figure 2 was composed of 1.5 wt/\% DCM (Exciton) in E7 (Merck), which was mixed by heating at $70^{\circ} \mathrm{C}$ for $\sim 16$ hours.

Cell preparation: The mixtures were capillary filled into $9 \mu \mathrm{m}$ planar-aligned cells made of indium tin oxide (ITO)-coated glass (Instec). They were annealed by heating them to above the isotropic temperature using a hot-stage (Linkam TP93), then cooled to $0.1^{\circ} \mathrm{C}$ below the isotropic-N* transition temperature while being mechanically rubbed and left for 3 hours. They were cooled at $\sim 0.5^{\circ} \mathrm{C}$ per minute to room temperature. This annealing gave a good Grandjean alignment of the chiral nematic phase and minimized the formation of oily streaks (as evident in the polarizing microscope images and the PL spectra).

Optical analysis: An Olympus BX51 optical polarizing microscope with a camera (QICam Fast1394) attached to the photo-tube was used to check samples and to record images of the optical textures.

The absorption of the clustomesogens in E7 was recorded using a UV-Vis spectrometer (Agilent 8453). The band-gap was measured by illuminating the sample with a halogen white light source (Ocean Optics HL-2000-FHSA) and recording the transmission spectrum on a fiber-coupled spectrometer (Ocean Optics USB2000+ UV-VIS) with a $600 \mu \mathrm{m}$-diameter fiber. PL was measured by illuminating with $365 \mathrm{~nm}$ and $405 \mathrm{~nm}$ (4.1 and $3.7 \mathrm{~mW}$ output) LEDs 
Submitted to

(Thorlabs). A 495-nm long-pass filter was used to prevent the detection of the LED emission.

Circularly polarized light was detected using a combination of a zero-order quarter-waveplate and a Glan-Thompson polarizer.

Electro-optic measurements: A voltage was applied across the cells using a $1 \mathrm{kHz}$ square wave applied at voltages up to $50 \mathrm{~V}_{\mathrm{p}-\mathrm{p}}$ using a voltage amplified (FCC electronics F10AP) function generator (Tektronix AFG-3022) monitored with a digitizing oscilloscope (Tektronix TDS224).

\section{Supporting Information}

\section{Acknowledgements}

SMM gratefully acknowledges the financial support of The Royal Society. M. Prévôt and M. A. Amela-Cortes thank ANR Clustomesogen (ANR-13-BS07-0003-01), FEDER and Région Bretagne for financial support.

Received: ((will be filled in by the editorial staff))

Revised: ((will be filled in by the editorial staff)) Published online: ((will be filled in by the editorial staff))

[1] M. Grell and D. D. C. Bradley, Adv. Mater., 1999, 11, 11.

[2] K.-H. Kim and J.-K. Song, NPG Asia Mater., 2009, $1,1$.

[3] S. G. Lukishova, L. J. Bissell, C. R. Stroud, R. W. Boyd, Opt. Spectrosc., 2010, 108, 3.

[4] S. H. Chen, D. Katsis, A. W. Schmid, J. C. Mastrangelo, T. Tsutsui, T. N. Blanton, Nature, 1999, 397, 6719.

[5] M. Grell, W. Knoll, D. Lupo, A. Meisel, T. Miteva, D. Neher, H.-G. Nothofer, U. Scherf, A. Yasuda, Adv. Mater. 1999, 11, 671.

[6] R. Porras Aguilar, J. C. Ramirez-San-Juan, O. Baldovino-Pantaleon, D. May-Arrioja, M. L. Arroyo Carrasco, M. D. Iturbe-Castillo, D. Sánchez-de-la-Llave, R. Ramos-Garcia, Opt. Express, 2009, 17, 5.

[7] K. Driesen, C. Vaes, T. Cardinaels, K. Goossens, C. Görller-Walrand, K. Binnemans, J. Phys. Chem. B, 2009, 110, 10575.

[8] M. Schadt, Annu. Rev. Mater. Sci. 1997, 27, 305.

[9] B. A. San Jose, S. Matsushita, K. Akagi, J. Am. Chem. Soc., 2012, 134, 48.

[10] B. A. San Jose, J. Yan, K. Akagi, Angew. Chem. Int. Ed. Engl., 2014, 53, 40. 
[11] K. Binnemans, J. Mater. Chem., 2009, 19, 4.

Submitted to

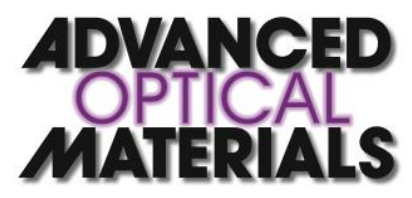

[12] S. Petoud, G. Muller, E. G. Moore, J. Xu, J. Sokolnicki, J. P. Riehl, U. N. Le, S. M.

Cohen, K. N. Raymond, J. Am. Chem. Soc., 2007, 129, 1.

[13] A. Y. Bobrovsky, N. I. Boiko, V. P. Shibaev, J. H. Wendorff, Adv. Mater., 2003, 15, 4.

[14] A. Bobrovsky, K. Mochalov, V. Oleinikov, V. Shibaev, Liq. Cryst., 2011, 38, 6.

[15] A. L. Rodarte, C. Gray, L. S. Hirst, S. Ghosh, Phys. Rev. B, 2012, 85, 3.

[16]A. Bobrovsky, K. Mochalov, V. Oleinikov, A. Sukhanova, A. Prudnikau, M. Artemyev, V. Shibaev, I. Nabiev, Adv. Mater., 2012, 24, 46.

[17] J. M. Winkler, S. G. Lukishova, L. J. Bissell, J. Phys. Conf. Ser., 2013, 414, 1.

[18] F. J. Duarte, L. W. Hillman, Dye lasers and their applications, 1990, Academic Press, Inc., p10-11.

[19] A. Bobrovsky, P. Samokhvalov, V. Shibaev, Adv. Opt. Mater., 2014, 2, 12.

[20] Y. Molard, F. Dorson, V. Cîrcu, T. Roisnel, F. Artzner, S. Cordier, Angew. Chem. Int. Ed. Engl., 2010, 49, 19.

[21] K. Kirakci, P. Kubát, J. Langmaier, T. Polívka, M. Fuciman, K. Fejfarová, K. Lang, Dalton Trans., 2013, 42, 19.

[22] M. Prevot, M. Amela-Cortes, S. K. Manna, R. Lefort, S. Cordier, H. Folliot, L. Dupont, Y. Molard., Adv. Funct. Mater. (In press).

[23] M. Amela-Cortes, A. Garreau, S. Cordier, E. Faulques, J.-L. Duvail, Y. Molard, J. Mater. Chem. C, 2014, $2,8$.

[24] Y. Molard, A. Ledneva, M. Amela-Cortes, V. Cîrcu, N. G. Naumov, C. Mériadec, F. Artzner, S. Cordier, Chem. Mater., 2011, 23, 23.

[25] M. A. Cortes, F. Dorson, M. Prévôt, A. Ghoufi, B. Fontaine, F. Goujon, R. Gautier, V. Cîrcu, C. Mériadec, F. Artzner, H. Folliot, S. Cordier, Y. Molard, Chemistry, 2014, 20, 28.

[26] M. N. Sokolov, M. A. Mihailov, E. V. Peresypkina, K. A. Brylev, N. Kitamura, V. P. Fedin, Dalton Transactions, 2011, 40, 6375.

[27] K. Kirakci, P. Kubát, M. Dušek, K. Fejfarová, V. Šícha, J. Mosinger, K. Lang, European Journal of Inorganic Chemistry, 2012, 2012, 3107.

[28] Amela-Cortes, M.; Cordier, S.; Naumov, N. G.; Meriadec, C.; Artzner, F.; Molard, Y., J. Mat. Chem. C., 2014, 2, 46.

[29] H. Shi, B. M. Conger, D. Katsis, S. H. Chen, Liq. Cryst., 1998, 24, 2.

[30] M. Prévôt, M. Amela-Cortes, S. K. Manna, S. Cordier, T. Roisnel, H. Folliot, L. Dupont, Y. Molard, J. Mater. Chem. C, 2015, 3, 5152.

[31] S. K. Nayak, M. Amela-Cortes, C. Roiland, S. Cordier, Y. Molard, Chem. Commun., $\mathbf{2 0 1 5}, 51,3774$. 
Submitted to

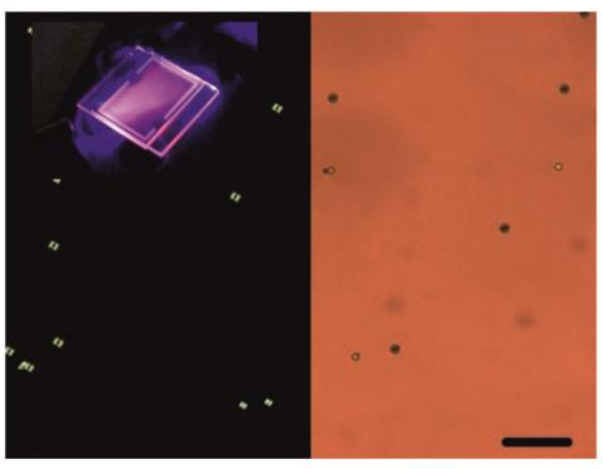

(a)

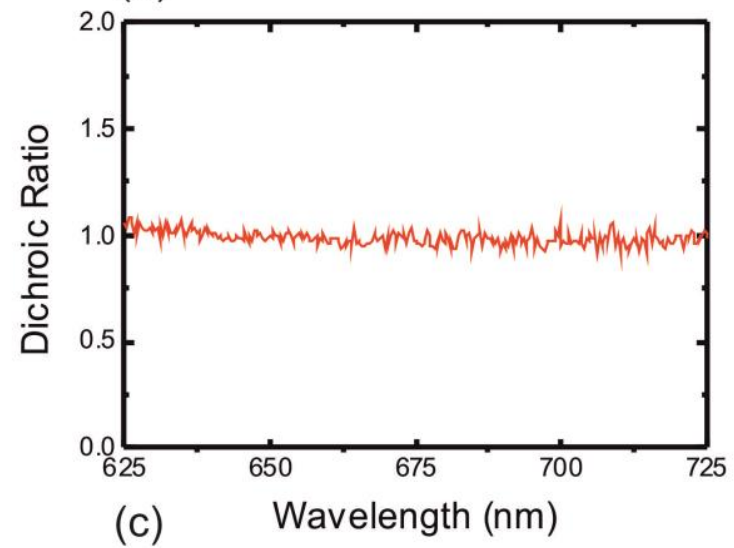

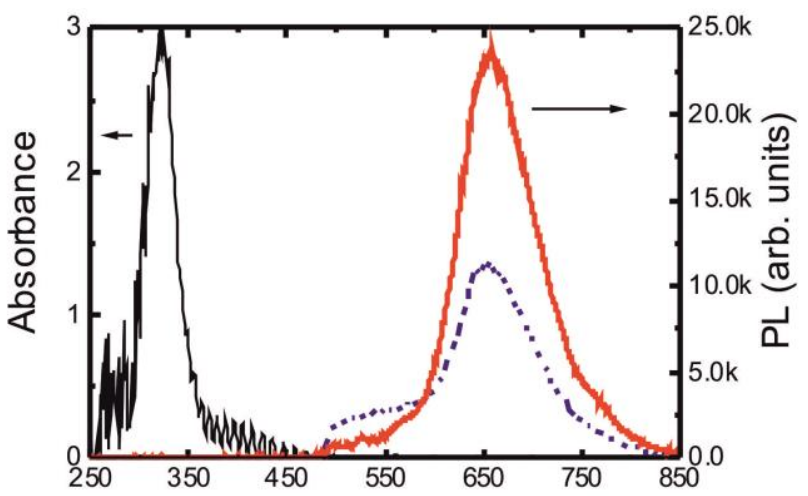

(b)

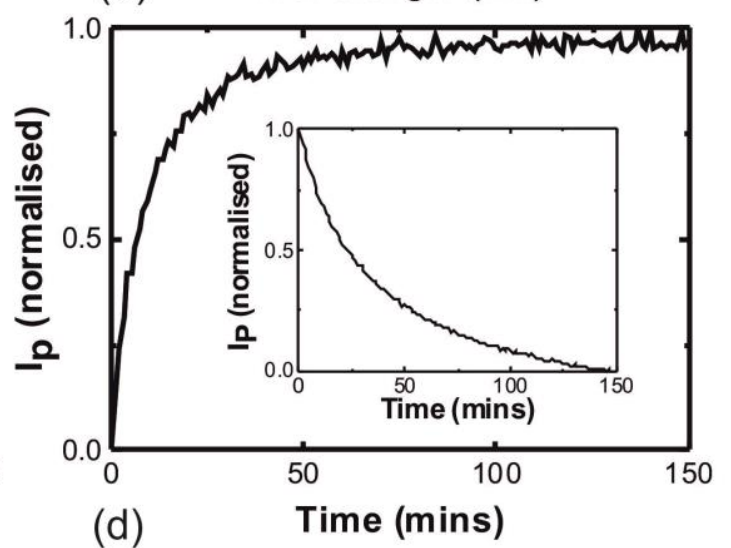

Figure 1. (Dispersion of Trisel $_{2}\left[\mathrm{Mo}_{6} \mathrm{I}_{8}\left(\mathrm{OCOC}_{3} \mathrm{~F}_{7}\right)_{6}\right]$ clustomesogen in a nematic LC in $9 \mu \mathrm{m}$ cells. (a) polarizing optical microscope images of the dark (left) and light (right) state of a clustomesogens-doped nematic LC - the dots are the $9 \mu \mathrm{m}$ spacer beads (inset: PL when optically excited using $365 \mathrm{~nm}$ irradiation); (b) Absorption (primary axis, black line) and phosphorescence (secondary axis: red line $-365 \mathrm{~nm}$ illumination, dashed line $-405 \mathrm{~nm}$ illumination); (c)Dichroic ratio of the mixture across the PL spectral range. (d)Time dependence of the PL intensity when optically excited at $365 \mathrm{~nm}$ at room temperature for a period of 150 minutes (inset: a fluorescent dye doped into the same nematic LC).) 


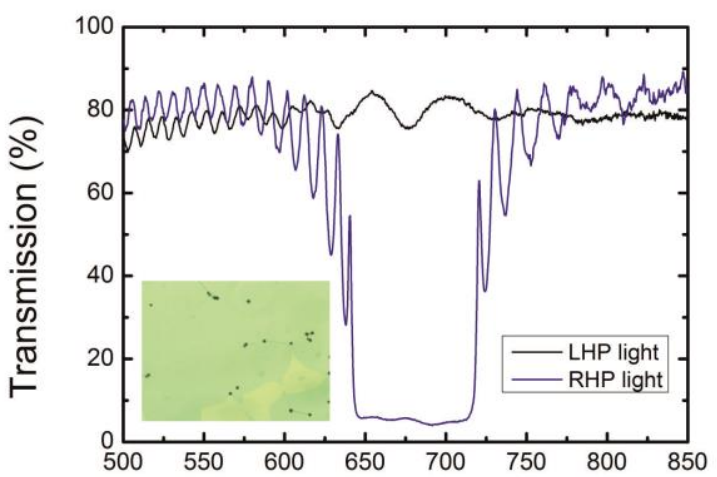

(a)

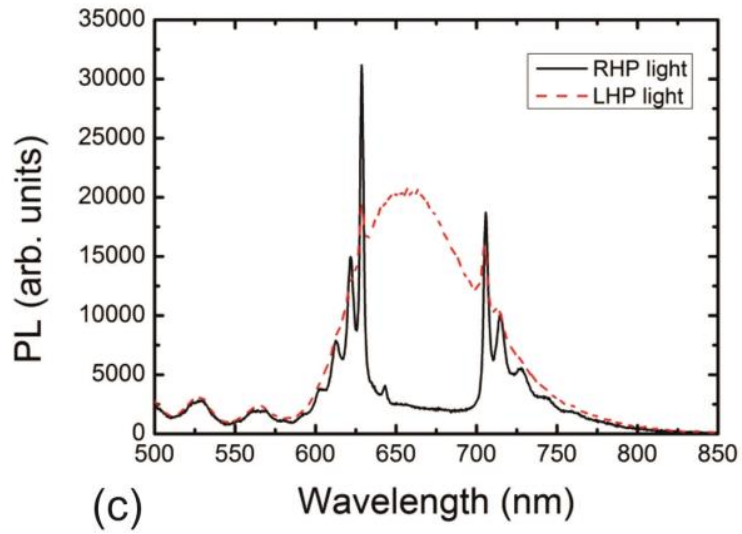

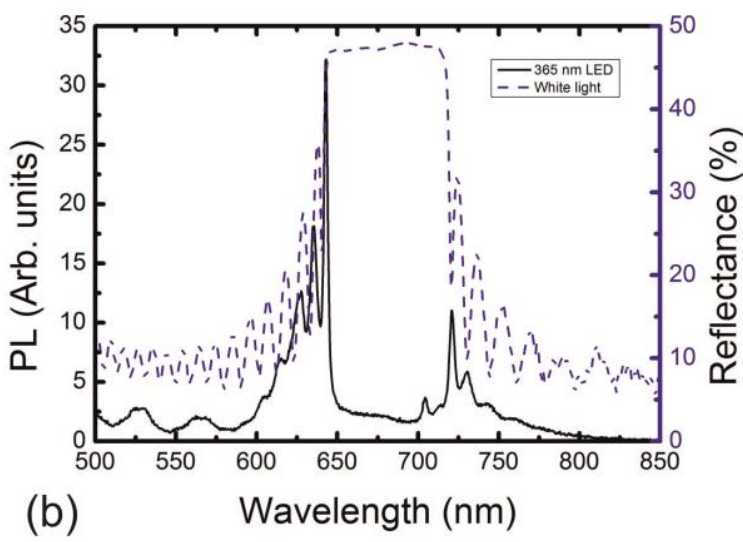

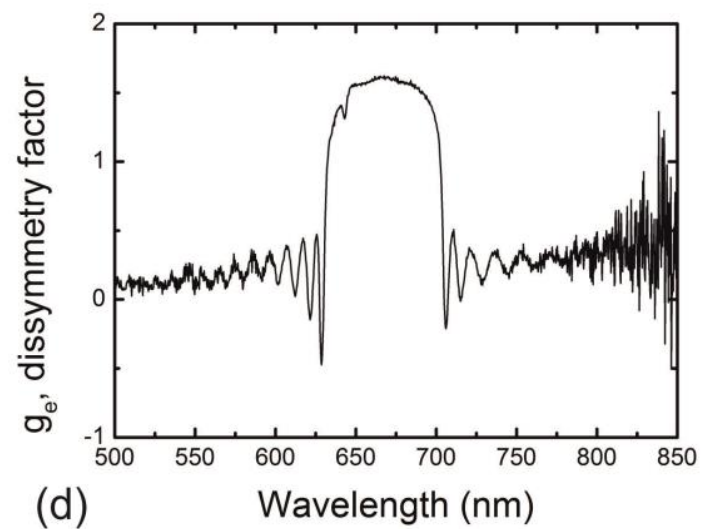

Figure 2. (Transmission and PL characteristics of a $\operatorname{Trisel}_{2}\left[\mathrm{Mo}_{6} \mathrm{I}_{8}\left(\mathrm{OCOC}_{2} \mathrm{~F}_{5}\right)_{6}\right]$ clustomesogen-doped chiral nematic LC. (a) Transmission spectrum for left and right CP incident light (inset: optical polarizing microscope image of the mixture in a $9 \mu \mathrm{m}$-thick glass cell); (b) the effect of the chiral nematic photonic band gap (dashed line) on the clustomesogens PL (solid line) under illumination with unpolarized light; (c) the clustomesogen-chiral nematic PL for left and right circularly polarized light; (d) the dissymmetry factor of the mixture.) 
Submitted to

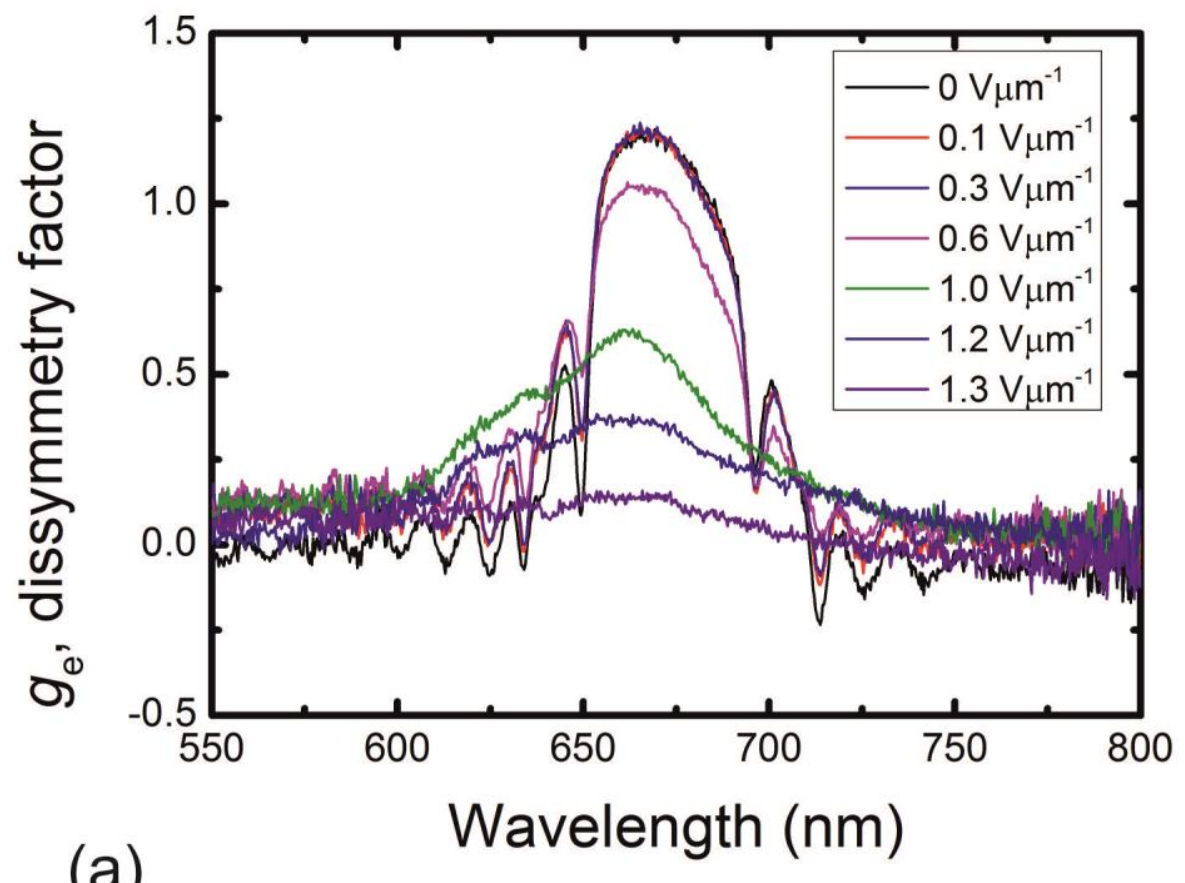

(a)

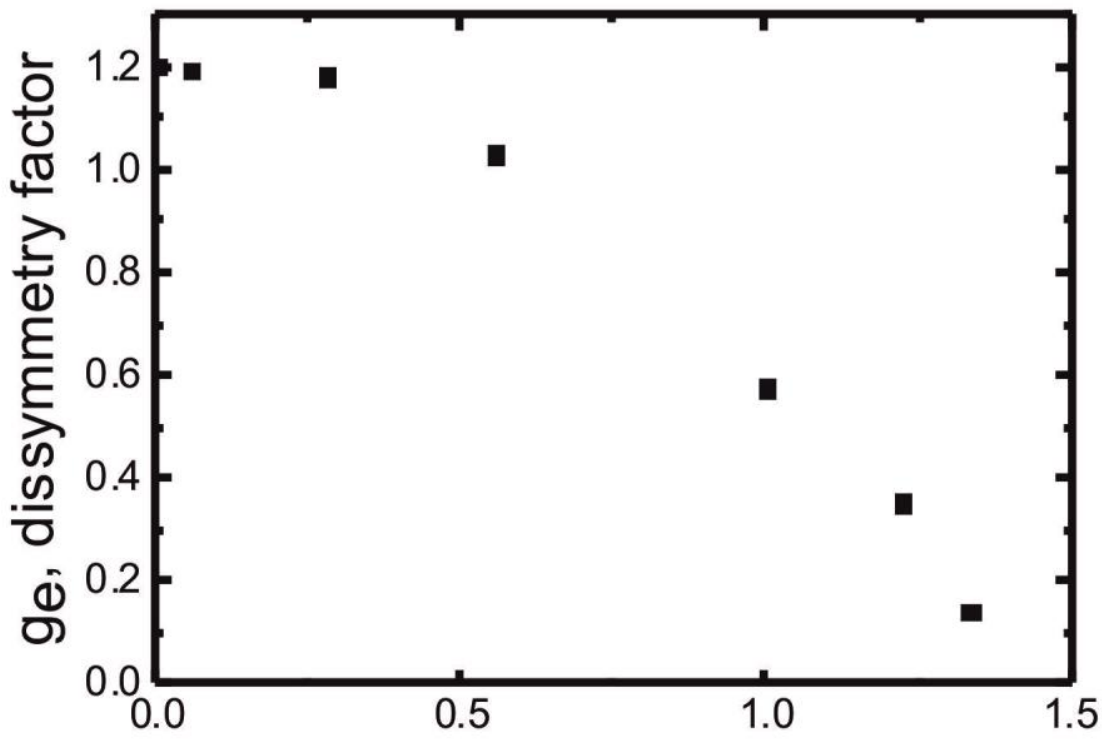

(b) Electric Field $\left({\left.\mathrm{V} \mu \mathrm{m}^{-1}\right)}^{-1}\right.$

Figure 3. (a) The change in dissymmetry factor on application of an electric-field; (c) The change in dissymmetry factor at a fixed PL wavelength $(670 \mathrm{~nm})$.) 
Submitted to

Active devices combining a light source, color generation and polarization control are of interest for applications from displays to quantum cryptography. We present work on transition metal clustomesogens - highly phosphorescent materials that are stable to illumination - dispersed in chiral liquid crystal materials to demonstrate their potential for use in next-generation polarized light sources.

Keyword (chiral nematic liquid crystals; clustomesogens; phosphorescence)

Simon M. Wood, Marianne Prévôt, Maria Amela-Cortes, Stéphane Cordier, Steve J. Elston, Yann Molard, Stephen M. Morris*

Polarized phosphorescence of isotropic, metal-based clustomesogens dispersed into chiral nematic liquid crystalline films

ToC figure ((Please choose one size: $55 \mathrm{~mm}$ broad $\times 50 \mathrm{~mm}$ high or $110 \mathrm{~mm}$ broad $\times 20 \mathrm{~mm}$ high. Please do not use any other dimensions))

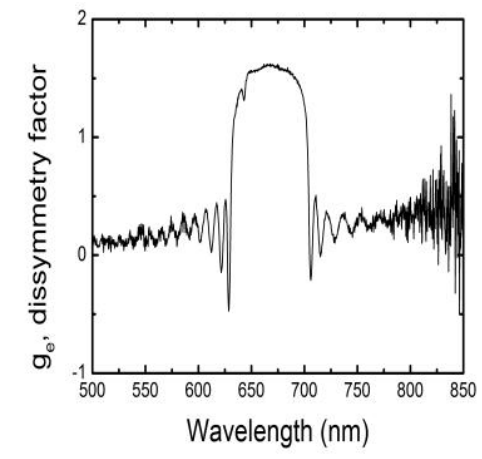




\section{Supporting Information}

for Adv. Opt. Mater., DOI: 10.1002/adom.((please add manuscript number))

Polarized phosphorescence of isotropic, metal-based clustomesogens dispersed into chiral nematic liquid crystalline films

Simon M. Wood, Marianne Prévôt, Maria Amela-Cortes, Stéphane Cordier, Steve J. Elston, Yann Molard, Stephen M. Morris

Structure of the clustomesogen
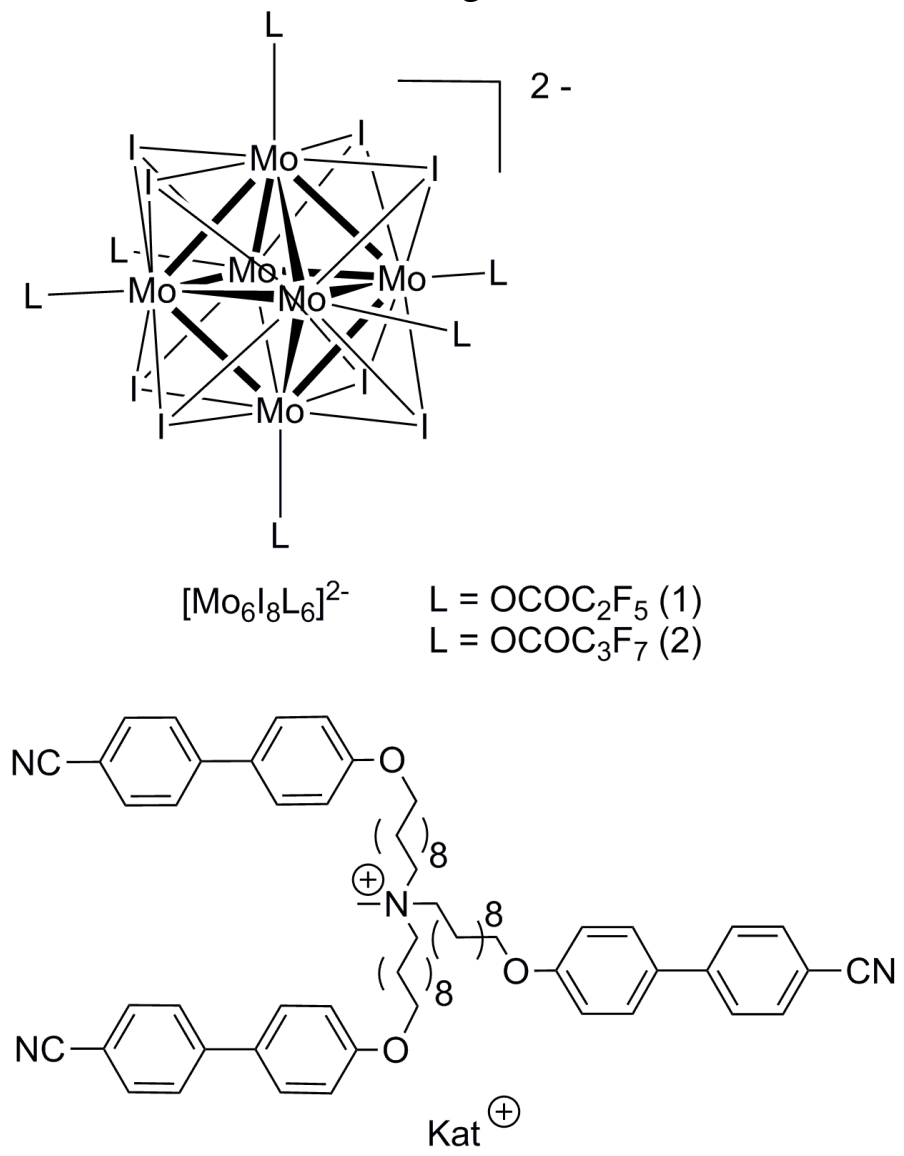

Figure S1. (The structure of the transition metal clustomesogens used in this study. General representation of octahedral molybdenum cluster units and of the organic promesogenic cation $\mathrm{Kat}^{+}$used in this work.)

$\underline{\text { Simulations of the transmission spectrum and density of photon states of the chiral nematic }}$ $\underline{\text { liquid crystal }}$ 


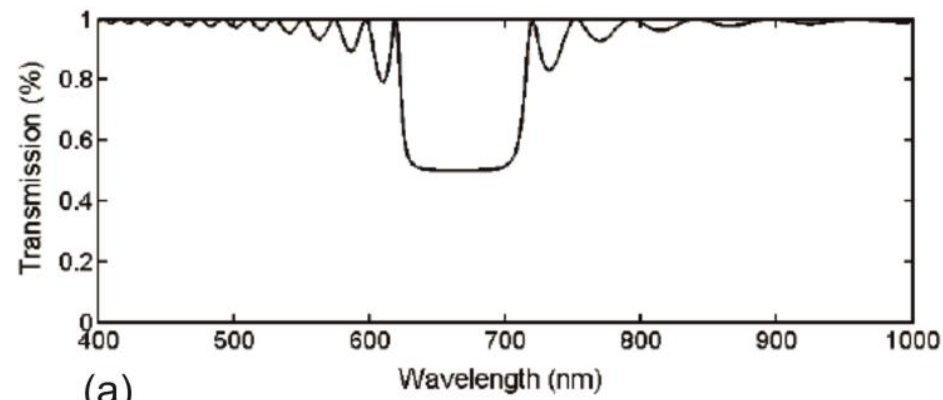

(a)

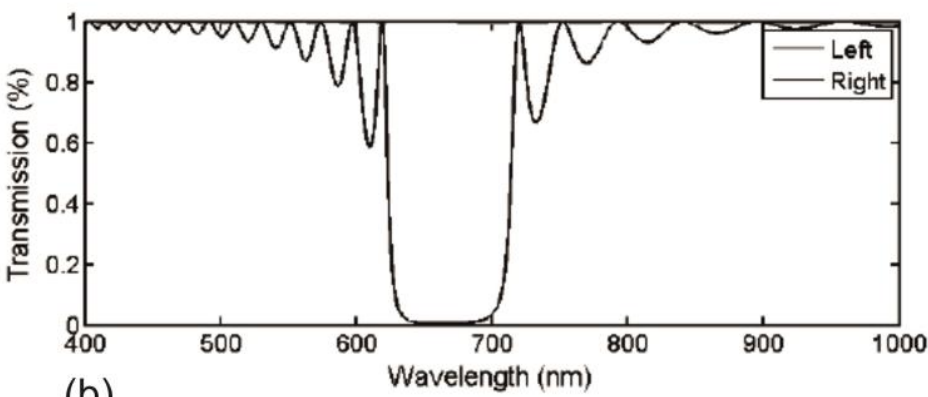

(b)

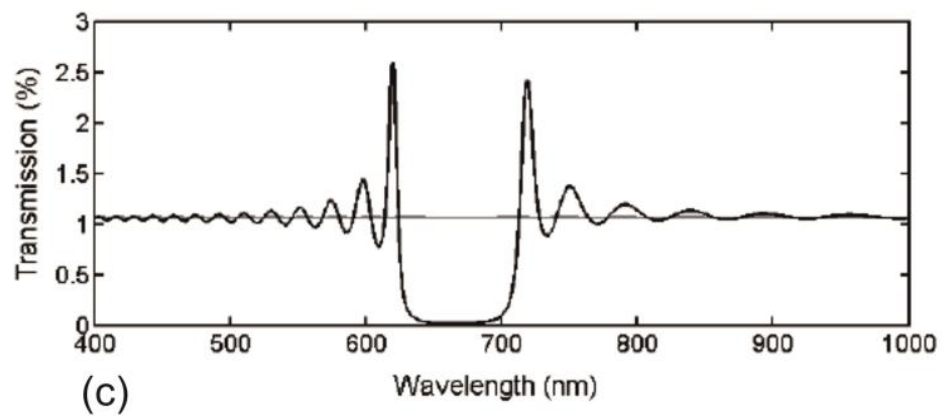

(Figure S2. Simulations of the transmission spectrum and density of photon states of the chiral nematic LC (a) transmission of unpolarized light; (b) transmission for left (grey line) and right (black line) CP light; (c) density of photon states for left (grey line) and right (black line) $\mathrm{CP}$ light.)

Simulations were carried out using the $4 \times 4$ Berreman Matrix ${ }^{[1]}$ to solve Maxwell's equations for light propagating parallel to the helix axis and the density of states was calculated using a similar approach to that outlined by Schmidtke and Stille. ${ }^{[2]}$ 


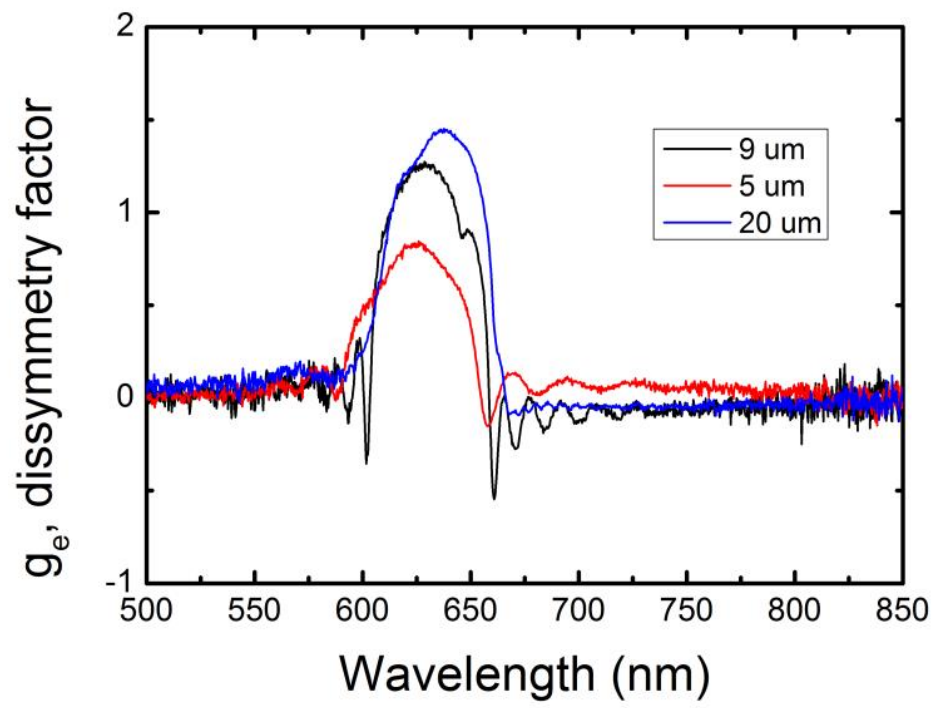

Figure S3. (The dissymmetry factor, $g_{\mathrm{e}}$, for different cell thicknesses $-5,9$ and $20 \mu \mathrm{m}$.)

Figure S3 shows the change in dissymmetry factor in different cell thicknesses - increasing between $5 \mu \mathrm{m}$ and $20 \mu \mathrm{m}$.

Degree of polarization:

The degree of polarization, $I_{L} / I_{R}$, is also a useful metric to judge such materials, as some that exhibit large dissymmetry factors do not have a large degree of polarization. In our case the degree of polarization is 9.6 at $670 \mathrm{~nm}$, comparing favourably to values calculated from the literature - for example $\sim 5$ for quantum dots ${ }^{[3]}$ and dye-doped chiral nematics. ${ }^{[4]}$

\section{Synthesis of clustomesogens:}

Tris (w-[4-(4'-cyanobiphenylyl)oxy]decyl] methylammonium bromide (Trisel-Br) ${ }^{[5]}$ and $\mathrm{Cs}_{2} \mathrm{Mo}_{6} \mathrm{I}_{14}{ }^{[6]}$ were obtained by the reported procedure and confirmed using analytical data. 


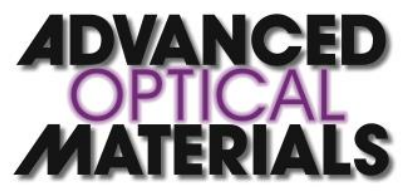

Starting materials were purchased from Acros, Alfa Aesar and Aldrich, and used without further purification unless otherwise stated.

$\mathrm{Cs}_{2} \mathrm{Mog}_{8}\left(\mathrm{C}_{2} \mathrm{~F}_{5} \mathrm{OCO}\right)_{6}$ : To a solution of $\mathrm{Cs}_{2} \mathrm{Mo}_{6} \mathrm{I}_{14}(1.5 \mathrm{~g}, 0.52 \mathrm{mmol})$ in $20 \mathrm{~mL}$ of acetone, a solution of silver pentafluoropropionate $(0.935 \mathrm{~g}, 3.42 \mathrm{mmol})$ in $10 \mathrm{~mL}$ of acetone was added under argon and in the dark. The mixture was left for $48 \mathrm{~h}$ in the dark and then filtered through a Celite pad. The red solution was then evaporated to yield a red-orange powder. ${ }^{19} \mathrm{~F}-$ NMR (acetone-d $\left.{ }_{6}\right): \delta(\mathrm{ppm})=-82.98(3 \mathrm{~F}),-120.64(2 \mathrm{~F})$. EDAX: Cs 2, Mo 6.4, I 8.7, F 59.2, no Ag.

$\mathrm{Cs}_{2} \mathrm{Mog}_{6}\left(\mathrm{C}_{3} \mathrm{~F}_{7} \mathrm{OCO}\right)_{6}$ : To a solution of $\mathrm{Cs}_{2} \mathrm{Mo}_{6} \mathrm{I}_{14}(1.5 \mathrm{~g}, 0.57 \mathrm{mmol})$ in $20 \mathrm{~mL}$ of acetone, a solution of silver pentafluorobutyrate $(1.1 \mathrm{~g}, 3.43 \mathrm{mmol})$ in $10 \mathrm{~mL}$ of acetone was added under argon and in the dark. The mixture was left for $48 \mathrm{~h}$ in the dark and then was filtered through a Celite pad. The red solution was then evaporated to yield a red-orange powder. ${ }^{19} \mathrm{~F}$ NMR (acetone-d $\left.{ }_{6}\right): \delta(p p m)-81.47$ (3F, s), -118.23 (2F, s), -127.32 (2F, s). EDAX: Cs 2, Mo 6.0, I 7.1, F 48, no Ag Trisel $_{2}\left[\mathrm{Mo6I}\left(\mathrm{C}_{2} \mathrm{~F}_{5} \mathrm{COO}\right)_{6}\right]$ : A solution of $\mathrm{Cs}_{2} \mathrm{Mo}_{6} \mathrm{I}_{8}\left(\mathrm{C}_{2} \mathrm{~F}_{5} \mathrm{COO}\right)_{6}(0.335 \mathrm{~g}, 0.118 \mathrm{mmol})$ in acetone was added drop-wise to a solution of Trisel- $\mathrm{Br}(0.261 \mathrm{~g}, 0.236 \mathrm{mmol})$ in dichloromethane. A white precipitate formed instantaneously. The mixture was stirred at reflux for $1 \mathrm{~h}$ and the white precipitate filtered through Celite ${ }^{\circledR}$. The solvent was evaporated to afford orange oil.

The same method was used as previously described and the product was obtained as an orange oil. ${ }^{1} \mathrm{H}-\mathrm{NMR}\left(400 \mathrm{MHz}, \mathrm{CDCl}_{3}\right)$ : 1.34-1.39 (72H, m), 1.71-1.83 (24H, m), 3.05 (6H, s), $3.17(12 \mathrm{H}, \mathrm{m}), 4.00(12 \mathrm{H}, \mathrm{t}, \mathrm{J}=6.6 \mathrm{~Hz}), 6.99\left(12 \mathrm{H}_{\mathrm{Ar}}, \mathrm{d}, \mathrm{J}=8.7 \mathrm{~Hz}\right), 7.53\left(12 \mathrm{H}_{\mathrm{Ar}}, \mathrm{d}, \mathrm{J}=\right.$ $8.7 \mathrm{~Hz}), 7.66\left(24 \mathrm{H}_{\mathrm{Ar}}, \mathrm{q}, \mathrm{J}=8.4 \mathrm{~Hz}\right) .{ }^{19} \mathrm{~F}-\mathrm{NMR}\left(375 \mathrm{MHz}, \mathrm{CD}_{3} \mathrm{COCD}_{3}\right)=-83.00(3 \mathrm{~F}),-120.61$ 
(2F); Elemental analysis : Found: C, 41.37; H, 3.83; N, $2.42 \% \mathrm{C}_{158} \mathrm{H}_{174} \mathrm{~N}_{8} \mathrm{O}_{18} \mathrm{~F}_{30} \mathrm{I}_{8} \mathrm{Mo} 6$

requires $\mathrm{C}, 40.95 ; \mathrm{H}, 3.78 ; \mathrm{N}, 2.42)$. EDS: Mo: 6; I: 7; F: 30; no bromine, no cesium.

Trisel $_{2}\left[\mathrm{Mo6I}\left(\mathrm{C}_{3} \mathrm{~F}_{7} \mathrm{COO}\right)_{6}\right]$ (2): The same method was used as previously described with

$\mathrm{Cs}_{2} \mathrm{Mo}_{6} \mathrm{I}_{8}\left(\mathrm{C}_{3} \mathrm{~F}_{7} \mathrm{COO}\right)_{6}(0.400 \mathrm{~g}, 0.127 \mathrm{mmol})$ and $\mathrm{Kat}-\mathrm{Br}(0.284 \mathrm{~g}, 0.255 \mathrm{mmol})$. The product was obtained as an orange oil. ${ }^{1} \mathrm{H}-\mathrm{NMR}\left(400 \mathrm{MHz}, \mathrm{CDCl}_{3}\right): 1.34-1.39(72 \mathrm{H}, \mathrm{m}), 1.71-1.83$

$(24 \mathrm{H}, \mathrm{m}), 3.06(6 \mathrm{H}, \mathrm{s}), 3.19(12 \mathrm{H}, \mathrm{m}), 4.00(12 \mathrm{H}, \mathrm{t}, \mathrm{J}=6.6 \mathrm{~Hz}), 6.99\left(12 \mathrm{H}_{\mathrm{Ar}}, \mathrm{d}, \mathrm{J}=8.7 \mathrm{~Hz}\right)$,

$7.53\left(12 \mathrm{H}_{\mathrm{Ar}}, \mathrm{d}, \mathrm{J}=8.7 \mathrm{~Hz}\right), 7.66\left(24 \mathrm{H}_{\mathrm{Ar}}, \mathrm{q}, \mathrm{J}=8.4 \mathrm{~Hz}\right) .{ }^{19} \mathrm{~F}-\mathrm{NMR}\left(375 \mathrm{MHz}, \mathrm{CD}_{3} \mathrm{COCD}_{3}\right)$ : -

$81.44(3 \mathrm{~F}, \mathrm{~s}),-118.17$ (2F, s), -127.30 (2F, s). Elemental analysis : Found: C, 37.87; H, 3.46;

$\mathrm{N}, 2.09 \% \mathrm{C}_{164} \mathrm{H}_{174} \mathrm{~N}_{8} \mathrm{O}_{18} \mathrm{~F}_{42} \mathrm{I}_{8} \mathrm{Mo}_{6}+5 \mathrm{CH}_{2} \mathrm{Cl}_{2}$ requires $\mathrm{C}, 37.68 ; \mathrm{H}, 3.05 ; \mathrm{N}, 2.08$. EDS: Mo:

6; I: 6.7; F: 41.2; no bromine, no cesium.

[1] Berreman, D. W. J. Opt. Soc. Am. 1972, 62, 502.

[2] J. Schmidtke, W. Stille, H. Finkelmann, and S. T. Kim, Adv. Mater., 2002, 14, 10.

[3] S. G. Lukishova, L. J. Bissell, C. R. Stroud, R. W. Boyd, Opt. Spectrosc., 2010, 108, 3.

[4] S. H. Chen, D. Katsis, A. W. Schmid, J. C. Mastrangelo, T. Tsutsui, T. N. Blanton, Nature, 1999, 397, 6719.

[5] R. S. Dickins, J. A. K. Howard, C. L. Maupin, J. M. Moloney, D. Parker, J. P. Riehl, G. Siligardi, J. A. G. Williams, Chem. A Eur. J., 1999, 5, 3.

[6] K. Kirakci, S. Cordier and C. Perrin, Z. Anorg. Allg. Chem., 2005, 631, 411. 